\title{
当教室における膝関節周辺骨折の治療成績
}

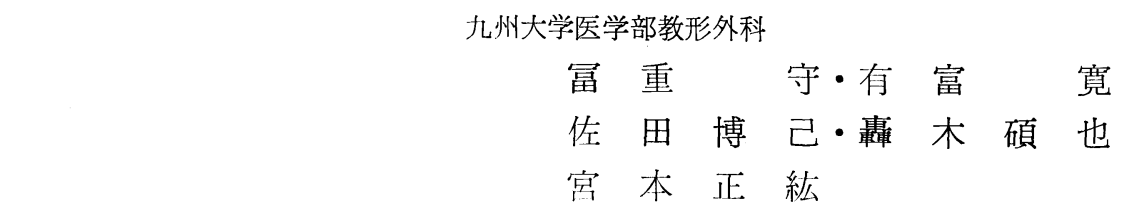

\section{Follow-up Results of Juxta-articular Fracture in the Knee}

By

\author{
M. Tomishige, H. Aritomi, H. Sada, \\ S. Todoroki \& M. Miyamoto \\ Department of Orthopedic Surgery, Faculty \\ of Medicine, Kyushu University.
}

\begin{abstract}
Seventy cases of juxta-articular fracture in the knee, seen in our outpatient clinic from January, 1960 to December, 1970 were reviewed by correspondence and examination.

Eighty eight fractures in seventy cases except fracture of the patella as follows: twentyone fracture sites in supracondyle femur, eleven in the condyle with joint surface, four only in the condyle, twelve in the intercondylar tubercle area of the tibia, thirteen in the condyle of tibia with joint surface, four only in the condyle, fourteen in proximal a third of the tibia and nine in the head of fibula.

Age of the patients ranged between four to sixty-six. However, this type of fracture is more common in male paients from second decade to fourth decade.

Follow-up results were reviewed from a point of view of deformity, pain, instability, and range of motion of the knee joint.

Fractures in tibia remained in wide range of motion in the knee joint, but that in distal end of the femur of the adult, even only in a condyle, in poor result in range of motion. Conservative treatment, such as traction, etc, revealed better result than operative management. It is cosidered that generally speaking, operative treatment was selectively done in severe cases with dislocation of fracture fragment, and surgical maneuvering might add injuries in the soft tissues around the joint.

Six cases out of twelve with the intercondylar tubercle fracture were revealed non-union but remained in wide range of motion unless associated with other complication.
\end{abstract}

膝関節周辺骨折は近年の交通事故の増加, 産業, ス ポーツの普及と共に增加してきている．膝関節は人体 最大の関節で荷重関節であると共に, 広範囲の可動性 が要求され，しかも複雑な内部構造を有しているた め, 骨折後に膝関節の運動障害, 動摇関節, 疼痛, 内 - 外反変形, 慢性関節炎, 二次性変形性関節症など の後遺症を残すととが多く，治療の予後に対する影響 は大きい，われわれは昭和 35 年 1 月より 昭和 45 年 12 月迄 11 年間に教室で取扱った滕関節周辺骨折例 (新鮮例, 陳旧例を含めて) について調査したので, その報告と 2,3 の考察について述べる。な怙，本調
查は当教室の入院カルテをあとに, アンケートと直接 検診により行った。

\section{症例並びに調査成績}

70 症例 88 骨折で，ほかに滕蓋骨々折が 36 骨折あ ったが今回は本骨折は除外した．年令は 4 才から 66 才で, 20 才代 30 才代が 6 割以上を占め, 大多数が男 性である.

部位別では, 88 骨折のうち大腿骨々折が 36 骨折で, このうち関節面におよがあのが 11 骨折ある，脛骨々 折は 42 骨折で, このうち顆間隆起単独骨折が 12 骨 
表 1

\begin{tabular}{|c|c|c|c|c|c|c|c|c|}
\hline \multirow{3}{*}{\multicolumn{2}{|c|}{ 膝屈曲度 }} & \multicolumn{2}{|l|}{ 大 } & \multirow{2}{*}{$\begin{array}{c}\text { 骨 } \\
\text { 部 }\end{array}$} & \multirow{2}{*}{\multicolumn{2}{|c|}{$\begin{array}{l}\text { 脛 } \\
\text { 顆 }\end{array}$}} & \multicolumn{2}{|c|}{ 骨 } \\
\hline & & \multirow{2}{*}{ 下 $1 / 3$} & 顆 & & & & 部 & \multirow{2}{*}{ 上 $1 / 3$} \\
\hline & & & $\begin{array}{l}\text { 関節に持 } \\
\text { よぶ骨折 }\end{array}$ & 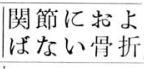 & $\begin{array}{l}\text { 顆間隆起 } \\
\text { 单独盄折 }\end{array}$ & $\begin{array}{l}\text { 関節に招 } \\
\text { 怘骨折 }\end{array}$ & $\begin{array}{l}\text { 関節に报上 } \\
\text { はない骨折 }\end{array}$ & \\
\hline $\begin{array}{l}\text { I } \\
\text { II } \\
\text { III } \\
\text { IV } \\
\text { V } \\
\text { VI }\end{array}$ & 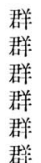 & $\begin{array}{l}9 \\
3 \\
4 \\
3 \\
1 \\
1\end{array}$ & $\begin{array}{l}1 \\
4 \\
4 \\
2\end{array}$ & $\begin{array}{l}2 \\
2\end{array}$ & $\begin{array}{l}8 \\
1 \\
3\end{array}$ & $\begin{array}{l}6 \\
2 \\
4 \\
1\end{array}$ & $\begin{array}{l}1 \\
3\end{array}$ & $\begin{array}{l}5 \\
6 \\
2\end{array}$ \\
\hline
\end{tabular}

折, 関節面に求よぶすの 13 骨折, 腓骨々頭部骨折 9 骨 折であった. これら骨折の問題となる可動性について 部位別にみると表 1 のごとくである. 但し, 可動籁困 は屈曲を主に日常生活の必要性より, I 群: 30 度以内 の届曲可能 (すなわち正坐可能なもの), II群：屈曲 31 度から 60 度迄可能なもの (胡坐, 横ずわり可能), III 群: 61 度から 130 度, IV 群：131 度加 170 度, V 群: 可動範囲 $0 \sim 10$ 度, VI 群: 不明の 6 群に分けた.

1. 大腿骨遠位端骨折

1）顆上骨折 (骨端線離開屯含む)：21 骨折のうち, I 群に 属するものは 9 骨折で， その中 6 例までが 12 才以下であり, 成人例に比べる之骨折も単純なものが 多い. 開放骨折は1例で他はすべて皮下骨折である. 全例共保存的療法で, 牽引療法 4 例, ギプス固定 2 例 であった. I 群中の残りの 3 例は, 16 才, 17 才, 19 才で, 観血的骨接合術を行ったすのが 1 例である. と れら 9 症例の正坐可能に 達するまでの期間は 19 才の 開放骨折例を除き， 3 力月以内である. 9 例中 1 例に 内反膝変形がみられた. これに対し 20 才以下を除い た 8 骨折では 6 例が 120 度までの屈曲しか出来ず, 高 度の屈曲障害を残している. このうち, 開放骨折が 2 例である. 観血的骨接合術を行ったものが 6 例, 牵引 法によったあのが 2 例である.なお 12 才から 20 才まで の骨折のうち, 前述の 3 例のほかに可動障害が残った 3 例は, いずれも観血的骨接合術が行われているもの である. 主な変形としては, 前方凸変形 4 例, 後方凸 変形 1 例, 内反膝 2 例の 7 症例がみ.られた.

2）大腿骨顆部骨折（関節面に㧍上ぶもの）：11 骨 折中 10 例は III, IV, V 群に含まれ, 胡坐, 横ずわり などは不能で高度の機能障害を残している.11骨折 中, 開放骨折は 2 例で, 観血的骨接合術を行ったもの が 8 例，旁引によったものが 3 例である. これらの骨 折症例中には 12 才以下の小児はみられなかった。 変
形亡しては, 内反 1 例, 外反 1 例がみられた. てれら は骨折癒合時の変形癒合によるものである，関節面に およぶ顆部骨折中，1例に I 群に属する可動性獲得が みられたむのがある.

症例：23才, 女性. バイクの後部坐席に乗車中事 故を㧍こして入院. 4 週間の鋼線牵引を行い, その後 10 週迄はギプスシーネ固定を行った. 退院時の可動 性は 180 度〜135 度であったが, 受傷後 9 年目の現在 正坐可能で全〈運動障害を認めずまた何の愁訴もない (図 1 a , b ).

3）大腿骨顆部骨折（関節面におよばぬすの）：4 骨折あり全例可動性は良好である. 観血的骨接合術を 行ったむの 1 例, 勒帯形成術十半月板摘出術 1 例で, ほかの 2 例はギプス固定を行った． 1 例に動摇関節を 認めた.

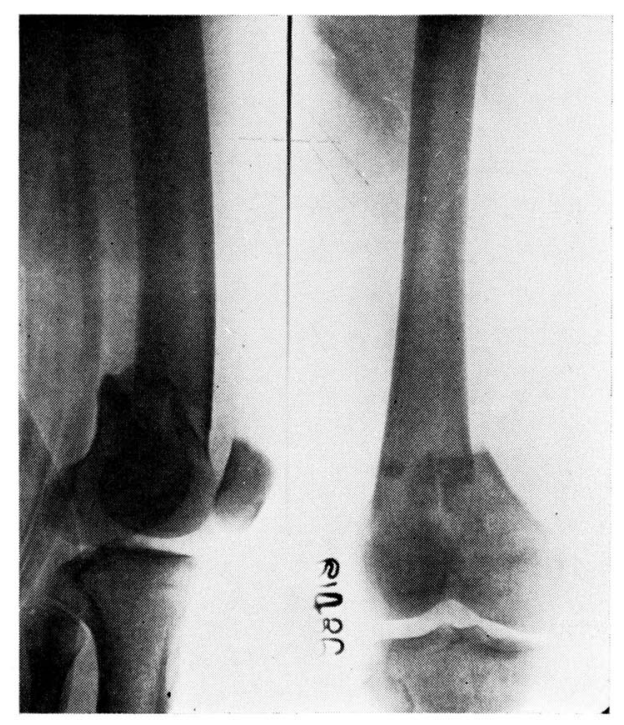

図1(a) 受 傷 時 


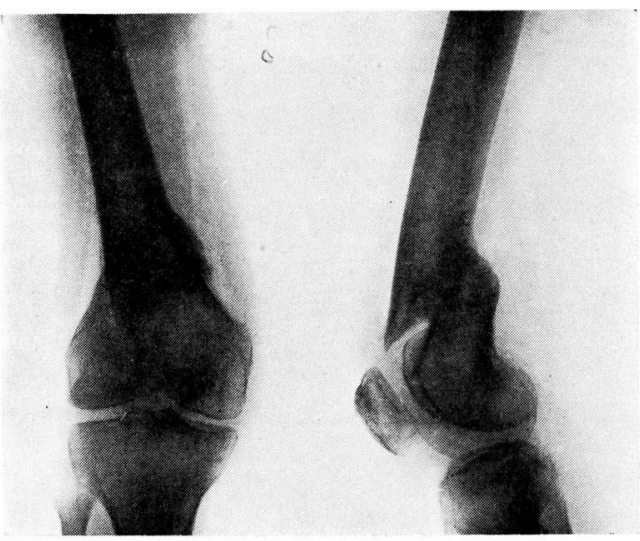

図 1 (b) 5 ケ月後

II. 下腿骨中枢端骨折

1）顆間隆起単独骨折

12 骨折中 I 群に含まれるむのが 8 骨折あり, 膝の 可動性は 良好である. III 群の 3 例は 1 例が膝蓋骨々 折を, 1 例が大腿骨々幹骨折, 大腿骨外顆骨折, 脛骨々 幹部骨折の 3 骨折を同時に合併していた。残りの 1 例 は 9 才の小児であるが，特に合併骨折もないのに， 1 年 4 力月後も疼痛が持続し, 180 度から 74 度の可動 性しか得られなかった．滕の動摇性はなく non-union が疼痛の原因かと考えられる. 12 例中，ギプスシー ネ固定 8 例, 骨接合術 3 例（このうち 1 例はメニスコ トミ一併用), 無処置 1 例であった. Non-union は 6 例にみられたが，その中 3 例には全く障害を認めなか った. 膝の動摇は 1 例に, 疼痛は II, III 群の 3 例に みられ, non-union との関連性を思わせた.

2）脛骨顆部骨折（関節面におよぶもの）

13 骨折中， I , II 群が 8 例あり，とのうち 6 例は I 群で 運動障害はない， III，IV 群に含まれるものも 5 例中 4 例は 90 度以内の屈曲が可能である（表 2 ）.

9 年後の現在 180〜135 度の運動範囲しか 得られなか った 1 例は，骨折の転位が強く開放骨折で, 術後血清 肝炎に䍜患したむので, 膝運動開始するまでの時間が 遅延し，8力月後に運動訓練を行わざるを得なかった 症例である. 13骨折中, 開放骨折は 5 例で, 観血的骨 接合術を行ったものが 10 例で，乙のうちメニスコト ミ一を同時に行ったものが 4 例あった．動摇関節を認 めるあのが 3 例, 外反変形が 2 例, 内反変形が 1 例, 外旋変形が 1 例みられたが，変形は何れも軽度であ る.
表 2 脛骨顆部骨折（関節面に括よら゙もの）

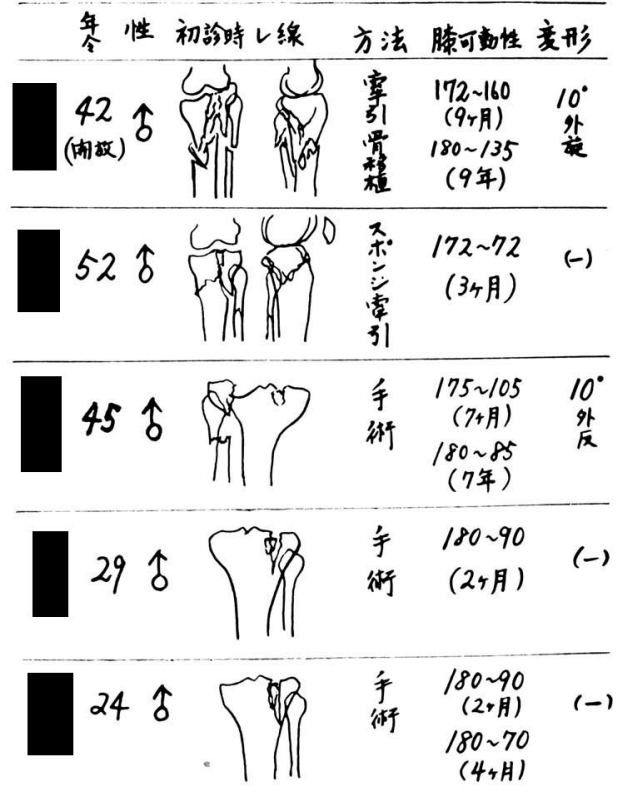

3）脛骨顆部骨折（関節面におよばぬもの）：4骨 折あり, 全例 I, II 群に属し, 可動性は良好である.

4）脛骨上 $1 / 3$ 部骨折 : 14 骨折で I， II 群が 11 例 であった． III 群の 2 例はいずれむ合併症を有した. 1 例は大腿骨々幹部骨折, 他の 1 例は股関節脱臼骨折, 恥骨骨折, 坐骨神経麻㾝などの合併症を有した. 14 骨 折中, 開放骨折は 8 例で，観血的骨接合術を行ったむ の 10 例, 率引によったあの 2 例, ギプス固定 2 例 である．動摇関節は脛骨隆起骨折，脛骨近位内顆骨折 を伴った 2 例にみ.られた. 内反変形をみたものが 1 例 ある.

5）腓骨々頭骨折：9骨折中，単独骨折は 2 例のみ で，他の 7 例は合併骨折を伴い，その予後は合併骨折 如何に低存している之考えられた. 外傷時既に腓骨神 経麻㾇を伴うものが認められた。

\section{総括および考察}

大腿骨遠位端部骨折では，滕関節滑動装置として重 要な膝上桽 (suprapatellar pouch) が障害されて屈 曲障害を来すととが多いことは諸家により述べられて いるところであるが，われわれの調査でも，12 才以 下の小児の症例と，関節に拈よばない顆部骨折を除け ば， 26 骨折のうち 60 度以内の屈曲を獲得した症例は 
7 例にすぎず，残りは高度の屈曲障害を残していた. 膝関節の屈曲障害は不動性固定よりも膝上囊の障害に 起因するといわれている. しかしながら，われわれの 症例では, 12 才以下の 6 症例は全例が $2 \sim 3$ 力月以 内に正常可動域まで復しており，乙れらの症例でも溙 上囊の損傷が皆無であったとは考えられず，成人の場 合亡の差が奈辺にあるか，な打疑問が残る，成人例で 1 例のみ正常可動域まで復した例は，保存的療法によ ったことなどを考え併せると，成人例では膝関節滑動 装置の障害が強く，手術侵襲により更に障害を増強さ せる傾いがある点, 観血的手術にはなお問題がある が，逆に非常に強固な固定を行うことが出来れば，膝 関節の早期運動訓練が可能となり, 拘縮発生の可能性 は少なくなると考えられる，ただ粉砕骨折，開放骨折
などでは仲々強固な固定が得難い症例があり，てれら の骨折をどうするかが今後の課題であろう.

脛骨上端部骨折では開放骨折が多く, 関節を構成す る軟部組織の損傷, 関節面の不整合により疼痛, 動摇 関節をひきおこしやすいと言われている. われわれ の症例では可動性は一般によく，43 骨折中 33 骨折は $60^{\circ}$ 度以上の屈曲が可能であった. 大多数は観血的療 法を行っているが, 完全な解剖学的形態への整復, お よび諸種靱帯の修復は困難で, 将来 Osteo-arthrosis または疼痛発生が憂慮される.

顆間隆起単独骨折は, 保存的療法で充分効果が得ら れているが, non-union となり，障害を残すあのは 摘出が必要となる場合がある.

\title{
わが教室における膝関節周辺骨折の治療
}

熊本大学整形外科

$\begin{array}{llll}\text { 大平 } & \text { 修・岡 } & \text { 隆 } \\ \text { 高木 克 } & \text { 公 星 子 } & \text { 亘 }\end{array}$

\section{Treatment of the Fracture of Knee in Our Clinic}

\section{By}

\author{
O. Ohira, T. Oka, K. Takagi \& W. Hoshiko \\ Department of Orthopedic Surgery, Kumamoto \\ University Medical School
}

\begin{abstract}
Follow up investigation on the fracture of knee was performed in 70 patients that were treated from 1955 through 1970 in our clinic. On the fracture of the knee except for patella, 16 cases were non-operatively and 23 cases were operatively treated. Ten cases out of 23 cases with operative management were applied to the K-U compression blade plate. It was clarified that the operative treatment with early movement and no plaster fixation gave the excellent result both anatomically (radiologically) and functionally. Regarding these point, it was proved that the K-U compression blade plate was one of the most excellent ideal tools.

On the fracture of the patella, 31 patient were treated in our clinic. Some of them were excellently trated using the wire acording to the Pauwels' method.

The fracture of the knee inclusive of patella should be treated according to not only anatomical but also functional standpoint, and especially in order to obtain the functional reduction, it might be necessary the useful rehabilitation planning.
\end{abstract}

当教室に入院し, 加療した膝関節周辺骨折の患者の 中, 調査し得た症例は 70 症例であり, このうち滕蓋
骨々折は 31 例, 膝蓋骨以外の膝関節周辺骨折は 39 例 である. 